\title{
DESAIN MODUL KIMIA BERBASIS KARAKTER UNTUK SISWA SMK DAN MA MATERI STRUKTUR ATOM DAN SISTEM PERIODIK UNSUR
}

\author{
Uswatun Hasanah ${ }^{1)}$, Lazulva) \\ 1) Pendidikan Kimia Fakultas Tarbiyah UIN SUSKA Riau \\ Email : Uswatunhasanah94@gmail.com
}

\begin{abstract}
The aim of this study is to produce character on chemistry module which is valid and practical. Type of this study is a research and development (R\&D) research using Borg and Gall's study design which covers the potential and problems, data collection, product design, validation design, revision design, and product trials. This study was conducted in Darul Hikmah Islamic High School, Darel Hikmah Vocational High School and Taruna Satria Pekanbaru Vocational High School. The subject of this study is all of the teachers in chemistry subject which consists of five teachers. The object of this study is character-based discipline pillar on chemistry module. The data from questionnaires. The instruments of this study were try-out validity questionnaires and practical questionnaires. The collecting data technique of this study was descriptive analysis technique. The module data was validated with average $88.6 \%$ (valid) and data tried-out to five chemistry teachers practicallited was tested with average $87.6 \%$ (practical). Based on the result finding, this study could be identified that character-based on chemistry learning is suitable and practical so can be applied for chemistry education especially on atomic structures and periodic components.
\end{abstract}

Keywords: module, character education, atomic structures, periodic components.

\section{PENDAHULUAN}

Tujuan pendidikan nasional yang tertera dalam Undang-undang RI nomor 20 Tahun 2003 tentang Sistem Pendidikan yaitu mengembangkan potensi peserta didik agar menjadi manusia yang beriman dan bertakwa kepada Tuhan Yang Maha Esa, berakhlak mulia, sehat, berilmu, cakap, kreatif, mandiri dan menjadi warga negara yang demokratis serta bertanggung jawab.[1] Untuk mewujudkan tujuan tersebut maka diperlukan guru yang terampil dalam mengajar. Sebagaimana yang kita ketahui guru adalah pendidik profesional,[2] oleh karena itu diharapkan mampu mendesain perangkat pembelajaran seperti bahan ajar yang dapat berupa handout, buku, lembaran kerja siswa, brosur maupun modul. Salah satu bahan ajar yang bisa membuat siswa belajar dengan atau tanpa bimbingan guru yang dapat memudahkan siswa belajar baik di rumah maupun di sekolah adalah modul.[3] Modul dapat membantu memecahkan masalah pendidikan dan memberi informasi positif karena dapat menuntun siswa untuk berfikir, bersikap dan berkembang lebih lanjut.[4]

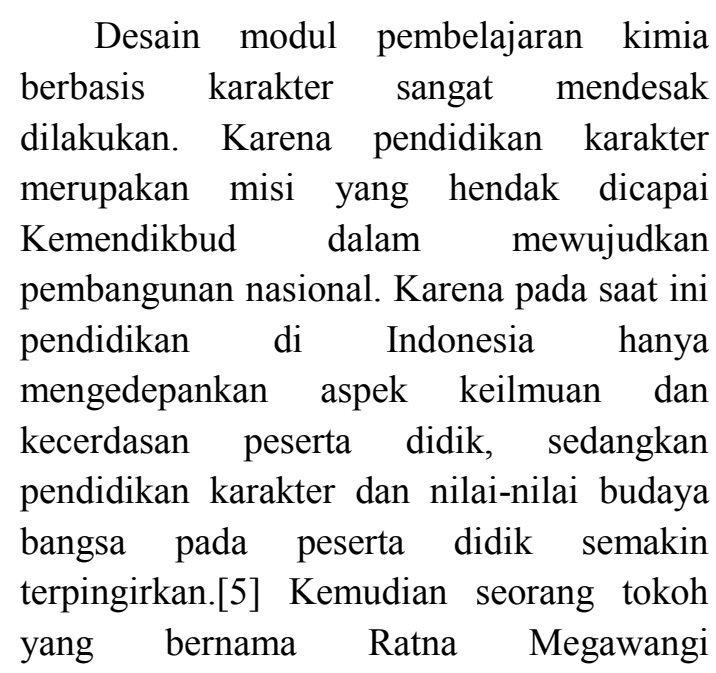


memunculkan sebuah model pendidikan alternatif yaitu "pendidikan karakter". Ratna Megawangi mengungkapkan bahwa karakter adalah kunci keberhasilan individu.[6] Sehingga salah satu kewajiban utama yang harus dijalankan oleh orang tua dan pendidik adalah melestarikan dan mengajarkan nilai moral kepada anak-anak dan siswa.

Selain itu, pendidikan karekter merupakan kewajiban dari Allah SWT untuk setiap umat Islam, sebagaimana yang terdapat dalam Firman-Nya dalam surat Ali Imran ayat 104:[7]

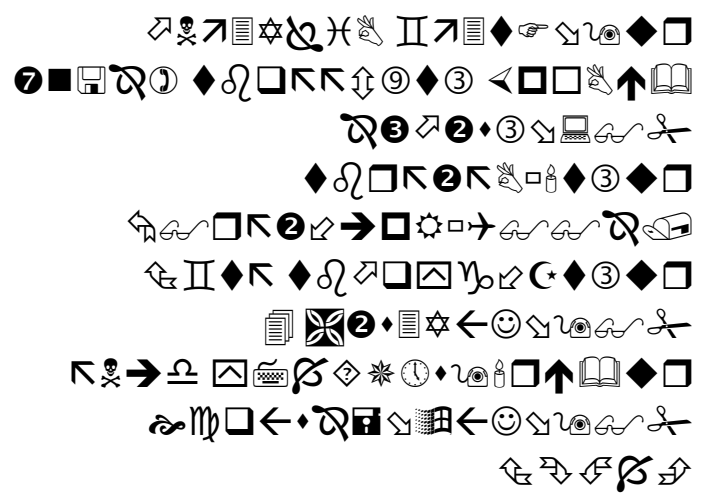

Artinya: "Dan hendaklah ada di antara kamu segolongan umat yang menyeru kepada kebajikan, menyuruh kepada yang ma'ruf dan mencegah dari yang munkar, merekalah orang-orang yang beruntung". (Q.S. Ali Imran: 104).

Ayat tersebut mengandung makna bahwa umat manusia diwajibkan untuk mengajak manusia menempuh jalan kebajikan dan melarang atau meninggalkan kemungkaran. Tujuannya adalah untuk membentuk umat yang berkarakter sesuai dengan syariat Islam yang dapat memberikan kebahagiaan hidup dunia dan akhirat. Dalam dunia pendidikan tugas utama seorang guru adalah membentuk karakter peserta didik yang berakhlak mulia. Langkah untuk memasyarakatkan pendidikan karakter telah banyak dilakukan, salah satunya yaitu dengan mengitegrasikan pendidikan karakter melalui perangkat pembelajaran. Pendidikan karakter dapat ditanamkan melalui pembelajaran yang terintegrasi didalam bahan ajar seperti modul.

Modul juga dapat digunakan dalam penyampaian materi kimia, seperti dalam pokok bahasan struktur atom dan sistem periodik unsur. Materi ini adalah materi dasar dan sangat penting, selain itu materi ini sebenarnya jika dikaitkan dengan kehidupan sehari-hari sangatlah berkaitan erat, yaitu terdapat nilai-nilai karakter didalamnya seperti mengajarkan peserta didik untuk hidup disiplin. Namun kebanyakan dari siswa tidak memahami peran penting materi kimia dalam kehidupannya. Hal ini membuat siswa banyak yang tidak tertarik dan mengalami kesulitan dalam belajar kimia, sehingga permasalahan yang muncul yaitu standar kompetensi yang ditetapkan belum tercapai dengan maksimal.

Selain itu, permasalahan-permasalahan lain yang berhubungan dengan karakter siswa saat ini juga dirasakan, yaitu ditunjukkan dari ditemukannya prilaku dan moral peserta didik yang tidak sesuai dengan misi Kemendikbud dalam mewujudkan pembangunan nasional, yaitu masyarakat yang berakhlak mulia, bermoral, beretika, berbudaya dan beradap berdasarkan falsafah pancasila. Terbukti dengan banyaknya berita tentang tawuran antar pelajar, kasus-kasus narkoba yang sering terlihat di televisi tidak jarang pemakainya juga masih menyandang status pelajar, anak yang tidak lagi memiliki sopan santun pada orang tua, dan yang sangat parah lagi yaitu ada anak yang berani membunuh orang tuanya sendiri.[8] 
Fenomena-fenomena nyata juga sering kita lihat seperti pelajar banyak yang bermain game online berjam-jam di warnet sepulang dari sekolah bahkan pada saat jam belajar sekolah, siswa sering bolos sekolah, cabut, bahkan ada juga yang merokok dan masih mengenakan seragam sekolah.

Hal yang sama juga terjadi pada siswa di Pekanbaru. Berdasarkan hasil wawancara dengan beberapa guru kimia di SMK Darel Hikmah, MA Darul Hikmah dan SMK Taruna Satria Pekanbaru diperoleh informasi bahwa tingkat karakter siswa belum sepenuhnya bisa dikatakan baik. Hal ini dikarenakan masih ada siswa sengaja tidak masuk kelas, bolos sekolah, bahkan cabut. Selain itu, saat proses pembelajaran berlangsung terdapat juga siswa yang tidak mengerjakan tugas yang diberikan oleh guru, terdapat yang main-main, mengantuk, tidak memperhatikan penjelasan guru, dan bahkan asyik berbicara dengan teman sebelahnya. Tingkat kedisiplinan siswa juga belum bisa dikatakan sangat baik, hal ini masih terdapat siswa yang datang terlambat kesekolah, dan keluar masuk saat belajar. Fenomena-fenomena ini belum sesuai dengan misi Kemendikbud. Oleh karena itu, penelitian ini dilakukan untuk menghasilkan modul kimia berbasis karakter sehingga dapat digunakan sebagai bahan ajar oleh guru dan diharapkan mampu menanamkan karakter disiplin pada siswa.

\section{METODE PENELITIAN}

\section{Jenis Penelitian}

Jenis penelitian ini termasuk penelitian dan pengembangan atau dalam bahasa inggrisnya disebut Research and Development.

\section{Waktu dan Tempat Penelitian}

Penelitian ini dilaksanakan pada bulan mei semester genap tahun ajaran 2015/2016 dan dilaksanakan di 3 (tiga) sekolah yang berada di Pekanbaru, yaitu SMK Darel Hikmah Pekanbaru, MA Darul Hikmah Pekanbaru dan SMK Taruna Satria Pekanbaru.

\section{Objek dan Subyek Penelitian}

Objek penelitian ini adalah modul pembelajaran kimia berbasis karakter disiplin untuk siswa SMK dan MA di Pekanbaru dan Subyek dalam penelitian ini adalah pihak yang melakukan validasi terhadap produk modul yang dikembangkan yaitu ahli desain media pendidikan, ahli materi pembelajaran dan ahli uji praktikalitas.

\section{Prosedur}

Prosedur dalam penelitian ini adalah model penelitian dan pengembangan yang diadaptasi oleh Brog and Gall (1983), dengan langkah-langkah: (1) Potensi dan masalah; langkah awal dalam penelitian dan pengembangan ini adalah mencari potensi masalah dalam proses pembelajaran kimia. (2) Pengumpulan data; setelah mengetahui potensi dan masalah langkah selanjutnya adalah mengumpulkan informasi yang dapat digunakan untuk mengatasi masalah tersebut, tahap ini meliputi; (a) Studi lapangan (observasi) untuk menemukan permasalah dalam proses belajar mengajar bidang studi kimia, mengidentifikasi bahan ajar kimia yang selama ini digunakan guru dan siswa, serta melakukan observasi atau wawancara untuk melihat kesesuaian bahan ajar yang digunakan dengan kurikulum dan karakteristik mata pelajarannya. (b) Studi literatur untuk menemukan konsep atau landasan teoritis yang memperkuat produk bahan ajar bentuk modul, dan memberikan 
gambaran hasil penelitian terdahulu sebagai bahan perbandingan untuk mendesain modul. (3) Desain produk, tahap ini adalah tahap tindak lanjut dari analisis temuan bahan ajar bentuk modul yang telah dilakukan pada tahap awal. Pada tahap ini dikembangkan desain produk awal modul berbasis karakter disiplin. (4) Validasi desain, dilakukan oleh pakar untuk mendapatkan koreksi dan masukan yang berkaitan dengan kelayakan isi, kebahasaan, penyajian, terhadap produk awal modul yang telah disusun. (5) Revisi desain, langkah setelah validasi adalah perbaikan terhadap produk modul berdasarkan masukan dan saran dari validator. Kekurangan-kekurangan yang diketahui pada proses validasi di perbaiki untuk menghasilkan modul yang lebih baik. (7) Uji coba produk, Setelah dinyatakan layak uji oleh ahli desain dan ahli materi, selanjutnya modul diuji cobakan kepada guru. Guru mengisi angket yang dilengkapi dengan komentar yang dapat memberikan masukan terhadap modul. Kemudian data dari angket yang telah di dapat dianalisis untuk melihat kepraktisan modul yang telah dibuat. (8) Revisi produk, pada akhir tahap dilakukan revisi atau perbaikan berdasarkan komentar guru, sehingga pada tahap akhir ini akan dihasilkan produk modul yang sempurna.[9]

\section{Instrumen dan Teknik Pengumpulan Data}

Instrumen yang digunakan dalam penelitian ini adalah lembar validasi ahli desain media pembelajaran dan lembar validasi ahli materi pembelajaran kimia, serta angket respon guru terhadap kepraktisan isi modul yang dilakukan dengan menggunakan skala Likert. Teknik pengumpulan data pada penelitian ini meliputi; observasi, wawancara, koesioner, dan dokumentasi.

\section{Teknik Analisis Data}

Untuk mengolah data hasil desain digunakan teknik analisis deskriptif kualitatif dan analisis data kuantitatif. Analisis data kualitatif yaitu mengolah data dengan mengelompokkan informasiinformasi dari data kualitatif yang berupa masukan, kritik, dan saran perbaikan yang terdapat pada angket. Selanjutnya metode analisis deskriptif kuantitatif yaitu menyusun secara sistematis dalam bentuk angka-angka presentase dari persepsi responden mengenai kelayakan modul yang telah di desain, dengan cara sebagai berikut:

1) Memberikan skor untuk setiap butir jawaban dalam angket dengan kriteria berikut:

$\begin{array}{ll}\text { Sangat Baik } & \text { : skor } 5 \\ \text { Baik } & : \text { skor } 4 \\ \text { Cukup Baik } & \text { : skor 3 } \\ \text { Kurang Baik } & \text { : skor 2 } \\ \text { Tidak Baik } & \text { : skor 1 }\end{array}$

2) Memberikan persentase nilai

$$
\begin{aligned}
& \text { Tingkat validitas }=\frac{\text { skor yang diperoleh }}{\text { skor tertinggi }} \times 100 \% \\
& \text { Tingkat praktikalitas }=\frac{\text { skor yang diperoleh }}{\text { skor tertinggi }} \times 100 \%
\end{aligned}
$$

3) Menginterpretasikan data

$$
\begin{array}{ll}
90 \%-100 \% & : \text { Sangat valid } \\
70 \%-89 \% & : \text { Valid } \\
50 \%-69 \% & : \text { Cukup valid } \\
30 \%-49 \% & : \text { Kurang valid } \\
20 \%-29 \% & : \text { Tidak valid. [10] }
\end{array}
$$

\section{HASIL DAN PEMBAHASAN}

Data hasil validasi terhadap modul pembelajaran kimia berbasis karakter ini adalah sebagai berikut: 


\section{Ahli Media Pendidikan}

Hasil penilaian oleh ahli media pendidikan yaitu Bapak Dr. Nursalim M.Pd terhadap modul yang telah didesain adalah sebagai berikut:

Tabel 1. Hasil validasi ahli media pendidikan terhadap modul kimia berbasis karakter.

\begin{tabular}{clcc}
\hline No & Kriteria Modul & $\begin{array}{c}\text { Nilai } \\
\text { Validasi }\end{array}$ & Kriteria \\
\hline 1 & $\begin{array}{l}\text { Format } \\
\text { penulisan }\end{array}$ & $95 \%$ & $\begin{array}{c}\text { Sangat } \\
\text { valid }\end{array}$ \\
2 & Bahasa & $90 \%$ & $\begin{array}{c}\text { Sangat } \\
\text { valid }\end{array}$ \\
3 & Tampilan modul & $94 \%$ & $\begin{array}{c}\text { Sangat } \\
\text { valid }\end{array}$ \\
4 & $\begin{array}{l}\text { Penempatan } \\
\text { Gambar }\end{array}$ & $90 \%$ & $\begin{array}{c}\text { Sangat } \\
\text { valid }\end{array}$ \\
& $\begin{array}{l}\text { Pengintegrasian } \\
\text { pendidikan } \\
\text { karakter pilar } \\
\text { disiplin }\end{array}$ & $80 \%$ & Valid \\
& Rata-rata & $89,8 \%$ & Valid \\
\hline
\end{tabular}

Hasil validasi yang dilakukan oleh ahli media pendidikan pada setiap aspeknya sebagaimana dianalisis secara kuantitatif dapat diinterpretasikan sebagai berikut:

a. Format penulisan meliputi: jenis dan ukuran huruf, dan sistem penomoran termasuk kategori sangat valid $(95 \%)$ artinya jenis dan ukuran tulisan, dan sistem penomoran pada modul sangat baik, sesuai, dan konsisten.

b. Aspek bahasa termasuk kategori sangat valid (90\%). Dengan demikian, bahasa yang digunakan dalam menyampaikan materi pada modul kimia sudah komunikatif sehingga mudah dipahami oleh siswa.

c. Aspek tampilan yang meliputi: kemenarikan cover, tampilan isi modul, pemilihan warna, tampilan teks dan gambar, penyajian modul, layout pengetikan, penggunaan background termasuk kategori sangat valid (94\%) Dengan demikian, tampilan modul sudah bagus, sangat sesuai, sudah tepat, sehingga diharapkan dapat membuat siswa tertarik dan merasa senang belajar kimia menggunakan modul.

d. Aspek pendukung termasuk kategori sangat valid (90\%). Dengan demikian penggunaan gambar, grafik maupun tabel dalam modul yang bertujuan sebagai pelengkap dan pendukung penyampaian materi sudah sesuai dengan teori, sangat jelas dan tidak buram.

e. Aspek pengintegrasian pendidikan karakter yaitu kesesuaian penempatannya dengan materi dalam modul termasuk kategori valid $(80 \%)$. Dengan demikian, pendidikan karakter khususnya karakter disiplin yang ditanamkan pada modul sudah baik dan sesuai atau ada keterkaitan dengan materi pelajaran. Sehingga hal ini diharapkan mampu untuk menanamkan nilai-nilai karakter disiplin pada siswa.

\section{Ahli Materi Pembelajaran}

Hasil penilaian oleh ahli materi pembelajaran yaitu Bapak Lazulva M.Si terhadap modul yang telah didesain adalah sebagai berikut:

Tabel 2. Hasil validasi ahli materi pembelajaran terhadap modul kimia berbasis karakter 
Hasil validasi yang dilakukan oleh ahli materi pembelajaran pada setiap aspeknya sebagaimana dianalisis secara kuantitatif dapat diinterpretasikan sebagai berikut.

a. Aspek isi atau materi termasuk kategori valid dengan presentase $80 \%$. Dengan demikian, materi yang terdapat pada modul sudah sesuai dengan kurikulum yang berlaku, keterkaitan antar konsepnya sudah baik dan penjabaran materinya sudah lengkap, dalam, akurat, dan sesuai dengan tingkat pemahaman dan perkembangan siswa.

b. Aspek tujuan meliputi kejelasan tujuan pembelajaran dan tujuan soal yang dapat mengukur ketercapaian kompetensi pada modul termasuk kategori valid dengan presentase $80 \%$. Dengan demikian, aspek tujuan pada modul kimia dapat dikatakan sudah memiliki tujuan yang jelas dan soalsoal yang terdapat di dalamnya dapat mengukur ketercapaian kompetensi siswa.

c. Aspek pengintegrasian pendidikan karakter pilar disiplin termasuk kategori sangat valid dengan presentase $100 \%$. Dengan demikian, pengintegrasian pendidikan karakter pilar disiplin dalam modul sangat dapat menanamkan nilainilai karakter disiplin kepada siswa karena sangat berhubungan dengan materi yang dipelajari dan langsung dihubungkan dengan ayat Al-qur'an.

d. Aspek bahasa termasuk kategori valid dengan presentase $86,7 \%$. Dengan demikian bahasa yang digunakan dalam menyampaikan materi pelajaran sudah komunikatif, mudah dipahami siswa, dan sesuai dengan EYD.

e. Aspek pendukung modul meliputi kategori sangat valid dengan presentase 90\%. Dengan demikian, aspek

\begin{tabular}{|c|c|c|c|}
\hline No & Kriteria Modul & $\begin{array}{l}\text { Nilai } \\
\text { validasi }\end{array}$ & Kriteria \\
\hline 1 & Isi atau materi & $80 \%$ & Valid \\
\hline 2 & Aspek tujuan & $80 \%$ & Valid \\
\hline 3 & $\begin{array}{l}\text { Pengintegrasian } \\
\text { pendidikan } \\
\text { karakter pilar } \\
\text { disiplin }\end{array}$ & $100 \%$ & $\begin{array}{c}\text { Sangat } \\
\text { valid }\end{array}$ \\
\hline 4 & Bahasa & $86,7 \%$ & Valid \\
\hline 5 & Pendukung & $90 \%$ & $\begin{array}{l}\text { Sangat } \\
\text { valid }\end{array}$ \\
\hline & Rata-rata & $87,34 \%$ & Valid \\
\hline
\end{tabular}

pendukung dapat membuat modul menjadi lebih baik, karena penyajian materi didukung oleh gambar, grafik dan simbol yang sangat sesuai dengan materi, dan terdapatnya soal latihan disemua akhir kegiatan belajar sehingga diharapkan tujuan pembelajaran dapat tercapai dengan baik.

$\begin{array}{lllr}\text { Data Keseluruhan } & \text { (Ahli } & \text { Media } \\ \begin{array}{l}\text { Pendidikan dan } \\ \text { Pembelajaran) }\end{array} & \text { Ahli } & \text { Materi }\end{array}$

Tabel 3. Perhitungan data hasil uji validitas secara keseluruhan

\begin{tabular}{ccc}
\hline No & $\begin{array}{c}\text { Variabel Validitas } \\
\text { Modul }\end{array}$ & $\begin{array}{c}\text { Persentasi } \\
\text { Keidealan }\end{array}$ \\
\hline 1 & Ahli media pendidikan & $89,8 \%$ \\
2 & Ahli materi pembelajaran & $87,34 \%$ \\
& \multirow{2}{*}{ Rata-rata } & $88,6 \%$ \\
& & $($ Valid) \\
\hline
\end{tabular}

Rata-rata hasil uji validitas modul kimia berbasis karakter pilar disiplin yang ditampilkan pada tabel 3 menunjukkan nilai sebesar $88,6 \%$ dengan kategori valid. Hal ini berarti modul pembelajaran kimia yang didesain sudah valid dan dapat diuji cobakan. Namun, berdasarkan komentar dan saran dari ahli media pendidikan dijadikan 
bahan perbaikan untuk menyempurnakan modul menjadi lebih baik lagi.

\section{Uji Coba Produk}

Modul yang telah divalidasi dan direvisi selanjutnya diuji cobakan kepada guru. Uji coba produk yang dilakukan pada penelitian ini adalah uji coba produk skala terbatas. Uji produk dilakukan pada tanggal 16-23 Mei SMK Darel Hikmah, MA Darul Hikmah dan SMK Taruna Satria Pekanbaru. Subyek uji produk adalah 5 orang guru mata pelajaran kimia dari 3 sekolah tersebut. Uji coba produk dilakukan untuk mengetahui presentase praktikalitas modul yang dinilai oleh guru sehingga dihasilkan produk modul yang praktis. Data hasil uji praktikalitas modul ini disajikan pada tabel berikut.

Tabel 4. Hasil praktikalitas modul kimia berbasis karakter

\begin{tabular}{clll}
\hline No & $\begin{array}{l}\text { Variabel } \\
\text { Praktikalitas }\end{array}$ & $\begin{array}{l}\text { Nilai } \\
\text { Praktikalitas }\end{array}$ & Kriteria \\
\hline 1 & $\begin{array}{l}\text { Aspek } \\
\text { tampilan } \\
\text { modul }\end{array}$ & $88,7 \%$ & Praktis \\
2 & $\begin{array}{l}\text { Aspek } \\
\text { Pemahaman } \\
\text { Siswa }\end{array}$ & $86 \%$ & Praktis \\
& $\begin{array}{l}\text { Terhadap } \\
\text { Materi }\end{array}$ & & \\
3 & Aspek Minat & $84 \%$ & Praktis \\
4 & $\begin{array}{l}\text { Penggunaan } \\
\text { modul }\end{array}$ & $88 \%$ & Praktis \\
5 & Bahasa & $90 \%$ & $\begin{array}{l}\text { Sangat } \\
\text { praktis }\end{array}$ \\
6 & Materi & $89,6 \%$ & $\begin{array}{l}\text { Sangat } \\
\text { praktis }\end{array}$ \\
& Rata-rata & $87,6 \%$ & Praktis \\
\hline
\end{tabular}

Berdasarkan hasil penilaian oleh validator uji praktikalitas tersebut, hal ini berarti secara keseluruhan modul ini praktis dalam menyampaikan materi kimia tentang struktur atom dan sistem periodik unsur. Sehingga diharapkan siswa dapat belajar secara mandiri. Selain itu, materi dalam modul disajikan secara luas, dan mendalam dan dihubungkan dengan nilai-nilai pendidikan karakter pilar disiplin yang juga dikaitkan dengan ayat-ayat Al-quran sehingga penggunaan modul dalam pembelajaran kimia diharapkan dapat mempengaruhi dan membuat siswa untuk meningkatkan sikap disiplin baik itu di lingkungan keluarga, sekolah maupun masyarakat.

\section{SIMPULAN DAN SARAN}

\section{Simpulan}

Tingkat kevalidan modul adalah $88,6 \%$ dan tingkat kepraktisan modul adalah $87,6 \%$, nilai ini menunjukkan bahwa modul telah valid dan praktis shingga digunakan di SMK Darel Hikmah Pekanbaru, MA Darul Hikmah Pekanbaru dan SMK Taruna Satria Pekanbaru.

\section{Saran}

Modul berbasis karakter ini dapat digunakan dalam pembelajaran kimia karena telah divalidasi dan diuji cobakan, dan sebaikanya modul ini di kembangkan lebih lanjut dengan melakukan eksperimen menggunakan kelas pembanding agar kualitas modul ini benar-benar teruji dalam hal pemanfaatannya.

\section{REFERENSI}

[1] Undang-undang RI No. 20 Tahun 2003. Tentang Sisdiknas 
[2] Undang-undang RI No.14 Tahun 2005. Tentang Guru dan Dosen

[3] M, Situmorang, dan Novalina. "Pengembanga Modul Pembelajaran Kimia SMA Melalui Inovasi dan Integrasi Pendidikan Karakter untuk Mempersiapkan Sumberdaya Berkarakter Menghadapi Persaingan Global". Jurnal FMIP Universitas Negeri Medan.5. 2015

[4] N, Mahnun, Media dan Sumber Belajar Berbasis Teknologi Informasi dan Komunikasi. Yogyakata: Aswaja Pressindo, 2014. Hlm. 62

[5] M, Agus, dan Martawijaya. "Pengembangan Model Pembelajaran Fisika untuk Meningkatkan Karakter Ilmiah Siswa SMA". Jurnal FMIPA Universitas Negeri Makassar. 2. 2015

[6] M, Syukri. "Pendidikan Berbasis Karakter Melalui Pembelajaran Konstektual". Jurnal Pendidikan Universitas Tanjungpura. 3. 2015

[7] Alqur'an dan terjemahan

[8] Theresia Felisiani, Enam Kejahatan, diakses 25 desember 2015 jam 08.00 WIB dari http//Pekanbaru.tribunnews.com/2015

[9] Sugiono. Metode Penelitian Kuantitatif, Kualitatif dan $R \& D$, Bandung: Alfabeta. 2014. Hlm. 298

[10] S, Arikunto, dan C, Fuadi. Evaluasi Program Pendidikan. Jakarta: Bumi Akasara, 2009. Hlm. 36 